In the remainder of the paper (pp. 557-566) the author examines critically, in the light of his analysis, the opinion of certain theologians.

It appears to me unfortunate that "faith" is used throughout this article as synonomous with "belief," for these two terms cover a range of mental experience wide enough to make possible a discriminating use of these terms.

One is surprised to find that the only contemporary psychologists who apparently have been consulted are those who wrote on this topic in the Dictionary of Philosophy and Psychology. I cannot help believing that a wider knowledge of psychological science on the part of theologians would redound to the advantage of both theology and psychology.

\title{
Bryn Mawr College
}

\section{J. H. LEUBA}

The Journal of Religious Psychology, including its Anthropological and Sociological Aspects, edited by G. Stanley Hall and Alexander F. Chamberlain. Volume V., I9I2.

(I) The Belief in Immortality. Simon SpIdLe. Pp. 5-51.

(2) Satan and his Ancestors from a Psychological Standpoint. Collys F. Sparkman. Part I. Historical Development, pp. 52-86; Part II. The Rise, Growth and Death of Satan, pp. 163-I94.

(3) The Genetic View of Berkeley's Religious Motivation. G. Stanley Hall. Pp. 137-162.

(4) Fear in Religion. W. D. Wallis. Pp. 257-304.

(5) The Psychology and Pedagogy of Doubt. Josian Morse. Pp. $418-428$.

(6) The Psychology of Religion. James B. Pratt. Pp. 383-394.

With the appearance of its fifth volume, The American Journal of Religious Psychology and Education modified its name and changed its editors. The disappearance of "Educational" and the appearance of "Anthropological and Sociological" indicate sufficiently the change that has taken place in the field covered by the journal.

(I) The first parts of this paper deal in a sketchy way with the several concepts of immortality; with the different theories of the origin of the belief; and with the grounds upon which the belief rests.

The last part, entitled "Present Status of the Belief," is an investigation by means of a questionnaire containing no less than thirty questions. It is much easier to draw false than right conclusions from the one hundred and seventy answers which the author received. Of the one hundred and four answers coming from the 
professional classes, seventy-five announce a belief in personal immortality. Apparently all these regard the doctrine of Christ's resurrection as "the crowning evidence of a future life." Of the forty-six answers received from high-school pupils only one doubts the reality of an after-life. And of the twenty answers from college students, again only one doubts personal immortality.

The information I have secured upon the belief of college students indicates, what is indeed apparent to any one acquainted with the times, that the questionnaire of Mr. Spidle fell into the hands of, or was answered almost exclusively by, persons who believe in immortality, but was not answered by all the persons belonging to the classes to whom the questionnaire was sent.

(2) The first half of Sparkman's paper deals with the historical development of Satan's forebears from antiquity to modern times. The second half seeks to discover the reasons for the existence of a belief that has taken such a deep hold on human nature. The author proposes to apply to the idea of the devil the psychoanalysis used by Freud for the discovery of psychic disorders. "Using race as a psychological unit, may it not have forgotten many processes analogous to those of the individual? May not its horizon have broadened and its consciousness in toto have found certain ideas unpalatable? If so, . . . the devil could be, in Freud's own language regarding the individual, 'the created output in a sublimated manifestation of various thwarted and repressed wishes of which it is no longer conscious." In this view the devil has been "an outlet for otherwise nauseating conscious thoughts."

(3) "To explain the philosopher psychologically is one of the chief new duties which our science now owes to the great speculative minds of the past." Berkeley is, according to Dr. Hall, a favorable example for "this new psychoanalysis." In a brief account of the philosopher's life we are shown how by his temperament and education he was tempted to a denial of the reality of matter. "His all-dominant wish was to exalt the cause of faith and reason above, and at the expense of, that of sense." "He would make a great coup which should bring consternation to the critics of religion. ...He would impeach and discredit the most ancient trusted oracles of mankind ... by showing that matter too was really immaterial, was only a practical postulate on the plane of sense, which must be, in fact, everywhere accepted by an act of faith."

His romantic missionary enterprises and his advocacy of the wonderful properties of tar-water confirm the indications of his 
early life, and throw such additional light upon the motivation of his philosophy that no student who would understand its raison d'être should omit the reading of Siris, during his lifetime the most popular of his works, but now almost forgotten.

(4) The chief purpose of the author seems to be two-fold. First to show that awe and reverence are essential and invariable elements in every true religious consciousness; secondly that the foundation of religion rests in individual as well as in social psychology. Here he opposes the theory of Durkheim according to which religion can be explained only by reference to social consciousness.

The paper reports a large number of experiences from the life of more or less primitive peoples, all of which elicit the same reaction, namely fear.

The author's definition of religion by means of fear, awe and reverence is subject to the criticism which I have offered in several of my writings. His contention that the origin of religion must be sought both in individual and in social psychology appears so nearly selfevident that when it is contradicted, it must be, it seems to me, because of a verbal misunderstanding.

(5) "The thesis of this paper is that doubt and belief are contrary psychical states, that the law of contrast holds between them, and that belief is the inducing or positive state, and doubt the induced or negative state." It is the inculcation in youth of beliefs that are antagonistic to those which experience interpreted by modern knowledge produces, which is the cause of the pathetic state of doubt so common in adolescence. "Doubt is not necessary; it is not a natural heritage of youth;-it is an unhappy state induced by dogmatism and unwise pedagogy."

(6) After a critical discussion of the three sources from which the psychologist of religion obtains his facts (individual experience in autobiographies, letters; answers to definite questions; objective expressions of social religion furnished by history, anthropology, and literature), Pratt passes to the question, What is the proper attitude of the psychologist toward the commonly assumed objective reality of the cause, or causes, of religious experiences? We are told that for its own protection science must act as if there were no interruptions in the sequence of phenomena. The psychologist should content himself with describing the phenomena as he finds them, leaving to others the guess work by which apparent breaks in experience are bridged over, that is, the hypothesis of supernatural interference and the "scientific" hypothesis of unconscious activity and others. 
"I cannot help thinking that it would ultimately lead to great disappointment, if not to positive scepticism, if we should sanguinely expect, as I fear many cultured religious people have been led to expect, that the psychological study of religion can demonstrate any of the truths of theology. And equally misleading does it seem to me to suppose, as some leading 'functional' psychologists seem to do, that the psychology of religion can ever so develop as to be in any sense a substitute for philosophy or theology." Psychology "must content itself with a description of human experience, while recognizing that there may be spheres of reality to which these experiences refer and with which they are possibly connected, which yet cannot be investigated by science."

There is not space here for a critical discussion of Professor Pratt's position. I may however be allowed to refer to my treatment of certain aspects of this problem on pages $244^{-261}$ of my book $A$ Psychological Study of Religion; its Origin, Function and Future.

Bryn Mawr College James H. Leuba

Zeitschrift der Religionspsychologie, 1911. Vol. V.

(I) Aufgabe und Methode der Religionspsychologie. Hermann Bauke. Pp. 97-104.

(2) Zur Frage nach der transzendental-psychologischen Methode in der Religionswissenschaft. Georg Wobrermin. Pp. 225-234.

(3) Religiöses Erkennen und Erkenntnistheorie. K. A. Busch. Pp. 209-218.

(4) Grundsätze und Aufgaben der Religionspsychologie. RoLand Schutz. Pp. 245-263.

(5) Das religionspsychologische Problem Zinzendorf. H. Lemmann. Pp. 327-336.

(6) Zur Psychologie des hysterischen Madonnenkultus. O. PFister. Pp. 263-271.

(I) The first of these papers is a criticism of an address by Wobbermin. The second is a retort by the latter.

Bauke defends the so-called "American school of religious psychology" against Wobbermin who finds it too exclusively naturalistic, and who, in order to make it adequate, would complete it by the addition of a "transzendental-psychologischen Aufgabe mit transzendental-psychologischer Methode." Bauke holds that the American psychologists have remained true to the methods of a strictly empirical science and believes that the transcendental-psychological 